\title{
DROP STONES RESULTING FROM SNOW-AVALANCHE DEPOSITION ON LAKE ICE
}

\author{
By B. H. Luckman \\ (Department of Geography, University of Western Ontario, London 72, Ontario, Canada)
}

\begin{abstract}
Amstract. Dirty snow avalanches have been observed to carry considerable amounts of rock debris on to lake ice at the foot of scree slopes. As ice breaks up in the spring thaw, this material is carried back and forth on ice floes and is gradually deposited in the lake. In some areas this produces typical drop stones of rock debris in predominantly fine-grained deposits. Most avalanche debris is very angular which enables avalanche drop stones to be differentiated from those of glacial or other drift-ice origins. However, where avalanches incorporate glacial debris, such deposits may be indistinguishable from those formed by floating glacier ice.
\end{abstract}

RÉsumé. Saupjudrage de ś́diments resultant des apports d'avalanches de neige sur la glace de lac. On observe que les avalanches de neige sale transportent une quantité considérable de débris rocheux jusque sur la glace de lac au pied des pentes d'éboulis. Lorsque la glace se brise au moment de la fusion printanière, le matériel est transporté çà et là par les glaces fottantes et est déposé graduellement dans le lac. Dans certaines zones ceci produit un saupoudrage de ś́diment caractéristique fait de débris rocheux dans des dépôts où dominent les matériaux fins. Beaucoup d'apports d'avalanches sont tı ès anguleux ce qui peut permettre de différencier les sédiment; saupoudré; issus d'avalanche de ceux dont l'origine est un glacier ou une congère construite par le vent. Cíp pendant, lcrique les avalanches ont incorporé des débris glaciaires, leurs dépôts sont impossibles à distinguer de ceux formé : par des fragments flottants de glace de glacier.

Zusammenfassung. Tropfsteine als Ergebnis von Schneelawinenablagerungen auf Seeeis. Es wurde beobachtet, dass schmutzige Schneelawinen beträchtliche Mengen von Felsschutt auf das Seeeis am Fusse von Geröllhalden bringen. Wenn das Eis in der Frühjahrsschmelze aufbricht, wird dieses Material auf Eisschollen hin und her getrieben und allmählich in den See abgelagert. In manchen Gebieten entstehen dadurch typische Tropfsteine aus Felsschutt in vorwiegend feinkörnigen Ablagerungen. Der meiste Lawinenschutt ist sehr eckig; dadurch lassen sich Lawinen-Tropfsteine von solchen unterscheiden, die glazialen Ursprungs sind oder anderweitig von Treibeis herrühren. Wo jedoch Lawinen glazialen Schutt enthalten, mögen solche Ablagerungen von jenen, die durch treibendes Gletschereis entstehen, nicht unterscheidbar sein.

THE geomorphic significance of snow avalanches in Arctic and alpine areas has been underestimated. Under favourable conditions, especially when travelling over surfaces of loose, unconsolidated rock fragments, avalanches may incorporate large amounts of rock debris (Rapp, 1960; Gardner, 1970; Luckman, 1972). Continued avalanche activity in such locations leads to the production of welldeveloped landforms known as avalanche boulder tongues (Rapp, 1959; Luckman, unpublished). Usually the avalanche debris is deposited within the terminal zone of the track but where avalanches extend on to ice-covered water bodies there may be considerable redistribution of these deposits.

Annual debris accumulation from rock falls and snow avalanches has been recorded on seven scree slopes in Surprise Valley, Jasper National Park, since 1968 (Luckman, I971, unpublished). Two of the sites studied flank lakes so that in several cases avalanche deposition has extended on to the lake ice. When this ice breaks up, the rock debris, ablated from the avalanche snow, is carried by the ice floes over the lake basin and subsequently deposited as the ice melts (Fig. I). This secondary deposition may be concentrated in one location or dispersed over the lakes depending on the manner of debris release (tilting, overturning or gradual ablation) and the pattern of drift-ice movement in response to the winds or lake currents.

The avalanche deposits themselves may range from pure snow to a dirty snow and rock admixture. The characteristics of the rock debris depend on its origin. The most common debris sources are scree slopes or loose debris swept from the cliff zone of the avalanche track. These materials are a characteristically heterogeneous, poorly sorted mixture of angular, often freshly broken fragments ranging from boulder to silt size (see Fig. I). Since the rock debris can be derived from any unconsolidated material in the avalanche track, it could also include fluvial or glacially moulded debris.

The major implications of these observations are three-fold.

(a) Although these specific observations only relate to two small alpine lakes over a relatively short time period (6 years), morphological evidence suggests these processes have been active over a much longer period (several thousand years?), and similar deposits have been observed on larger water bodies 
elsewhere in the Canadian Rockies, in Scandinavia (Rapp, 196o, fig. 48) and on sea ice in the Canadian Arctic (Bones, unpublished, pl. 14). This suggests that, over long periods of time, snow avalanches and other mass movements (rock falls, slush avalanches, etc.) could locally deposit significant amounts of debris on lake or near-shore ice. Estimates from debris-accumulation measurements on screes with considerable avalanche erosion indicate mean annual deposition of the order of $0.5^{-5} \mathrm{~mm} \mathrm{~m}^{-2}$ year-1 (see Luckman, unpublished, p. 273).

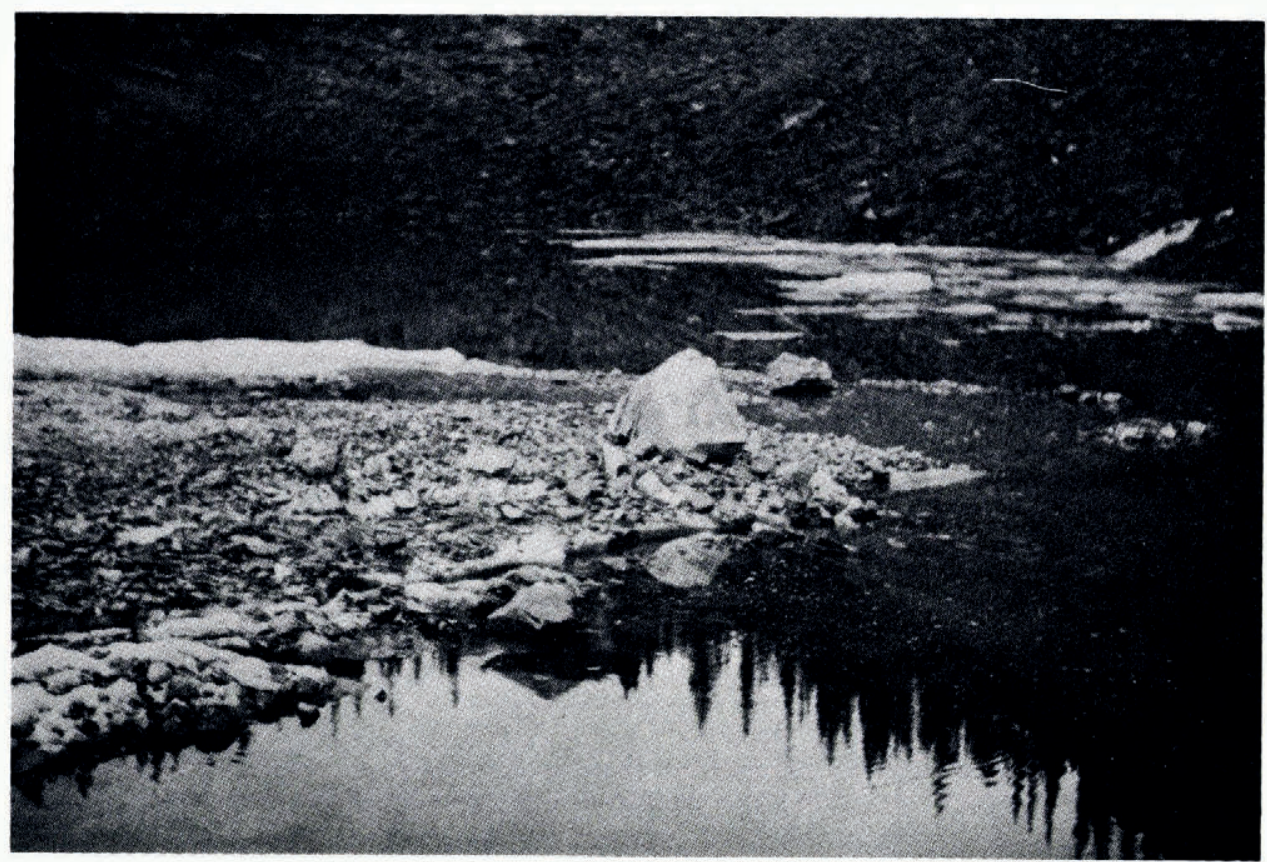

Fig. I. Partially submarged ice foe on Lake Helen, Surprise Valley, Jasper National Park, 8 June 197o. The thick d:bris cover is typical of avalanche-incorporated scree material. The large boulder is about $0.20 \mathrm{~m}^{3}(1.2 \mathrm{~m} \mathrm{long})$.

(b) The dispersal and melting of this debris-covered ice may result in the formation of "drop stones" in areas of otherwise predominantly finc-grained sediments (lacustrine or marine). Such deposits are commonly ascribed to the action of floating glacier ice or drift ice which derive their rock debris from glaciers, fluvial deposition on near-shore ice (Dangeard and Vanney [1974]) or ice-foot erosion of beach material (Dionne, 1974). Since the vast majority of avalanche drop stones arc markedly angular, it should be possible to differentiate them by their morphology (absen se of rcunded, polished or striated debris and their locale (evidence of past or present avalanche activity near the shore). However, where avalanches have incorporated till or fluvial material this distinction cannot be made. An important corollary of this is that in some cases the presence of striated or polished drop stones is not conclusive evidence for floating glacier ice.

(c) The dispersal of avalanche deposition by lake ice may inhibit the development of typical avalanche landforms in the lowest part of avalanche tracks which terminate in lakes.

\section{Acknowledgements}

The author wishes to thank McMaster University and the National Research Council of Canada for support during field work.

\section{MS. received 31 fuly 1974}




\section{REFERENGES}

Bones, J. G. Unpublished. Process-morphology interaction on Arctic debris slopes, S.W. Devon Island, Canada. [M.Sc. thesis, McMaster University, Hamilton, Ontario, 1971.]

Dangeard, L., and Vanney, J.-R. [1974.] Les dépôts glacio-marins actuels et anciens. (In Le glaciel. 1er colloque international sur l'action géologique des glaces flottantes, 20-24 avril 1974, Institut National de la Recherche Scientifique ... ., Ste-Foy, Québec. [Québec], Institut National de la Recherche Scientifique, Université de Québec, p. 9-13.)

Dionne, J.-C. 1974. How drift ice shapes the St. Lawrence. Canadian Geographical Journal, Vol. 88, No. 2, p. 4-9.

Gardner, J. 1970. Geomorphic significance of avalanches in the Lake Louise area, Alberta, Canada. Arctic and Alpine Research, Vol. 2, No. 2, p. 135-44.

Luckman, B. H. 1971. The role of snow avalanches in the evolution of alpine talus slopes. Institute of British Geographers. Special Publication No. 3, p. 93-1 io.

Luckman, B. H. 1972. Some observations on the erosion on talus slopes by snow avalanches. (In Slaymaker, H. O., and McPherson, H. J., ed. Mountain geomorphology. Vancouver, Tantalus Press, p. 85-92.)

Luckman, B. H. Unpublished. Scree slope characteristics and associated geomorphic processes in Surprise Valley, Jasper National Park. [Ph.D. thesis, McMaster University, Hamilton, Ontario, 1973.]

Rapp, A. 1959. Avalanche boulder tongues in Lappland. A description of little-known landforms of periglacial debris accumulation. Geografiska Annaler, Vol. 41, No. I, p. 34-48.

Rapp, A. 1960. Recent development of mountain slopes in Kärkevagge and surroundings, northern Scandinavia. Geografiska Annaler, Vol. 42, Nos. 2-3, p. 65-200. 